\title{
Women Trafficking In Pakistan: Gravity Of The Menace And Causes
}

\author{
Farooq-e-Azam Cheema \\ Bahria University, Karachi Campus \\ Tayyaba Zarif \\ Shaheed Benazir Bhutto University \\ Aziz - un- Nisa \\ Department of Education \\ University of Karachi
}

\begin{abstract}
The objective of this project paper is to gauge various factors underlying the internal and transnational trafficking of girls, women and children in Pakistan and to review the gravity and blueprint of the menace. Besides, this study endeavors to identify the most vulnerable section of the population in Pakistan in particular. This research work is primarily based on a review of secondary literature and interviews with the trafficking victims and the officials of the agencies engaged in prevention of human trafficking and the officials from certain NGOs working towards rehabilitation of the victims. Primary data was collected through interviews with the trafficking victims to get first hand information about their ordeals in order to secure an outlook into the dynamics of menace of domestic trafficking in Pakistan. For that purpose, 65 abused women were interviewed, majority of them lodged in the shelter houses in Karachi. Besides, this study also used periodic reports produced and published by various independent international bodies. Study concludes that poverty is the main underlying factor for this menace that leads to their economic and sexual abuse. Besides, gender disparity, abysmal literacy rate among the women in rural areas, and unawareness about legal privileges, lack of political and administrative will behind enforcement of anti-trafficking laws are also the contributing factors. Study found that these factors act in combination to bring about plight of the women in this region. Outcomes of this study have wide ranging practical implications including recommendations on identifying the factors that cause such trafficking and, accordingly, discovering the sections of society more vulnerable to internal and transnational trafficking. The study found that internally displaced people are usually more exposed to this menace. The study also highlighted internecine role of the law enforcement agencies especially the police.
\end{abstract}

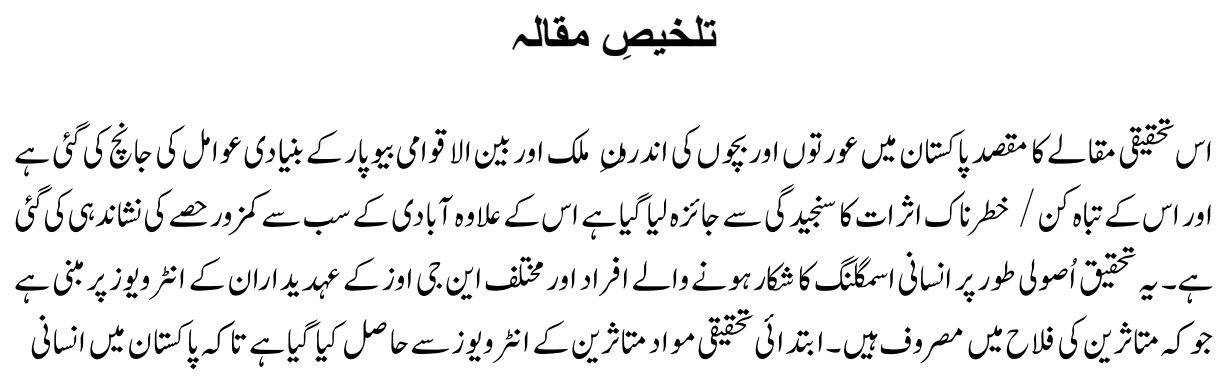




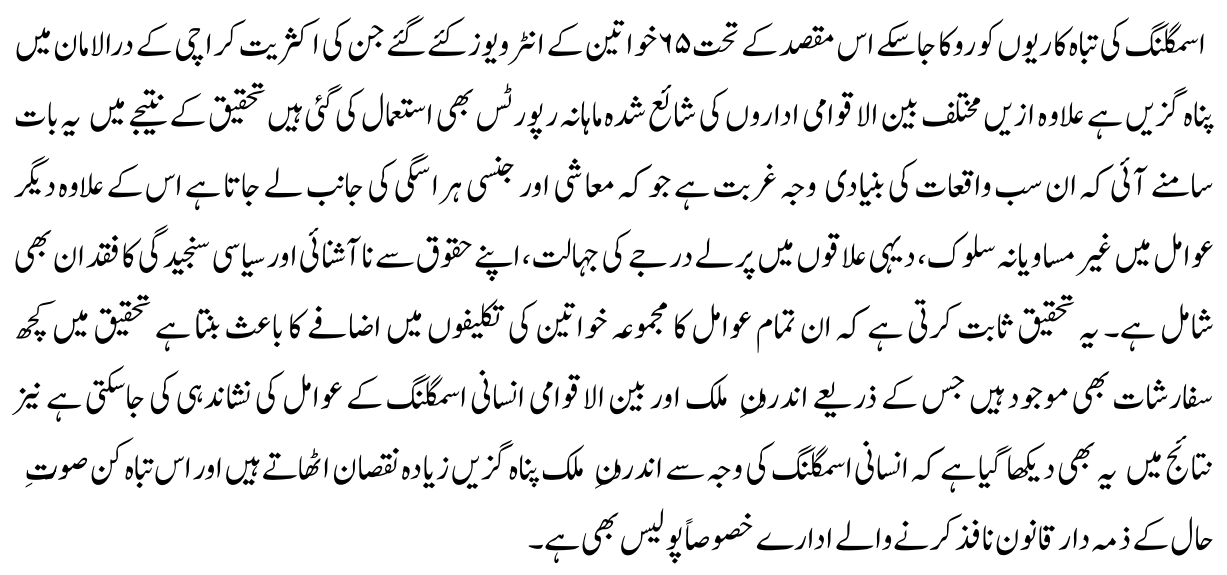

Key Words: Women trafficking, trafficking victims, economic and sexual abuse, gender discrimination

\section{Problem Background and Research Question}

Pakistan is believed to be quite essentially a country of origin, passage as well as destination place for trafficked women who end up into forced labor and prostitution. It has only recently managed to get off the thorny hook of the Tier two status that it had been perched on for not adequately complying with the Trafficking Victims Protection Act of 2000 (TVPA). Here, boys and girls are frequently traded and rented to work in structured begging syndicates, household and farming forced labour, and prostitution. Some independent observer bodies and NGOs have hinted at factual slave markets within Pakistan where women, girls and children are traded like beasts.

US State Department's 2013 report on Trafficking in Persons gives terrible details of women trafficking in Pakistan from Iran, Afghanistan, and Bangladesh, and back, mainly for prostitution. Women trafficking in and out of Pakistan has been very common from its inception. During partition, thousands of women were abducted on both sides of Indian and Pakistani borders and were hauled for sale or forced prostitution. Creation of Bangladesh, subsequently, surged thousands of women in Pakistan - a string that still continues even after more than four decades since then.

Connivance and even active support and complicity by the law enforcement agencies especially the police is a serious obstacle in dealing with the menace. On part of the rulers it has always been insufficient political will and capacity to address the issue. Our governments have never maintained record on the number of women trafficked. It is also perhaps because many occurrences of women trafficking especially the internal ones are never reported and registered. Our police system is known for punishing the victims of 
trafficking rather than the culprits. Most importantly, our governments have yet to enter into any bilateral agreement with its neighboring countries to combat the menace.

Hence, this study is being conducted to identify the cause of high level women trafficking within and abroad. Though factors like weak financial background, illiteracy and ignorance highest level of social injustice, crime against humanity, extreme brutally of the women's rights, and lawlessness in general, are the main factors that make the women an easy prey of the exploiters, this study endeavors to delicately identify the aspects underpinning the rampant women trafficking, to ascertain the most susceptible fragment of the populace and to work out measures with a potential to rein in the nuisance.

Besides, it has been reported that in our patriarchal society, trafficked women are often communally ostracized, rendered unable to redeem their societal repute. Accordingly, this study is also aimed at to identify the kind of stress such women undergo once having gone through such ordeal, and what kind of response and treatment they are meted out by their immediate society including their family and friends. At the end, recommendation will be offered to combat this menace.

\section{Research Question}

What are the causes of rampant women trafficking in and across Pakistan and what kind and level of mental stress these women pass through even after having been recovered from the captivity of the perpetrators?

\section{Literature Review}

Ahmad and Sarkar (1997) define women trafficking as all deeds involved in abducting, capturing, recruiting, and transporting of women within and astride national frontiers with an intention to sell or exchange them, subjecting them to slavery under the garb of marriage, forced labor, sexual abuse and prostitution, or to pass them through sale of human organ process.

The United Nation resolution No. 49/166 adopted on December 23, 1994, defines women trafficking as "the illicit and clandestine movement of the women and girls across national and international borders, with the end goal of forcing them into sexually or economically oppressive and exploitative situations for the profit of recruiters, traffickers and crime syndicates, such as forced domestic labor, false marriage, clandestine employment and false adoption". According to the United Nations Office on Drugs and Crime report published in 2004, women trafficking crime is cursing the countries towards unlawful outcomes. Shahinian (2002) calls it slavery of the contemporary days. 
A report by the Pan American Health Organization (2001) on trafficking of women shows that Southeast Asia spawns the highest quantity of women victims trafficked globally. The report says that over 225,000 each year are transported across India, Bangladesh, Nepal, Burma and Pakistan, depicting these countries as key source and destination countries for trafficked women - Nepal being the most bountiful of all for the traffickers (Asmita, 1998). She says that in the last decade, 100,000 Nepali women and girls were found in India brothels. Shah, S. (2004) endorses the point saying that about 5000-7000 Nepalese girls are trafficked to India daily who finally land in the brothels. The author says that even in Pakistan 200,000 Bangladeshi women were trafficked in the last ten years who were mostly sold in the slave market in the last decade of the previous century.

Asian Human Rights Commission report (2011) labels Pakistan as a country of origin, passage as well as destination place for trafficked women who end up into forced labour and prostitution. Javed (2011) endorses this claim of the AHRC report and says that women are sold across the country like animals - the better the 'condition' the higher price she will fetch. The purchased women are then consigned to captivity or moved to other parts of the country or abroad for re-sale. Shah (2004) says this scenario be speaks our soulless society where women are traded as commodities that are out for sale. It is reminiscent of the mediaeval ages wherein one could buy and sell young girls and women. This point is supported by the Trafficking in People Report (TIP) published by the United States Department of State in 2011wherein Pakistan is classified as a Tier 2 country. This term is used for those countries which are not completely complying with the provisions of Trafficking Victims Protection Act of 2000 (TVPA), though they are making effort to do so.

Khowaja et al (2012) say that within Pakistan, the women are trafficked from interior Sindh and Southern Punjab. This heinous business is undertaken by none other than the powerful landlords and politicians with the full information and shelter of the local police and other agencies and authorities. Mostly victims of these landlords are the girls and women whose families owe money to these landlords and are unable to repay the loan. They further explain that during natural disasters like floods and earthquakes, this business further soars. A research study conducted by the Aurat Foundation and USAID in 2012 on Internal Trafficking of Women and Girls in Pakistan states that at least half a million people in Pakistan remain displaced at any time due to natural disasters like floods in Sindh, earthquakes in northern and southern parts of the country, and the rampant armed conflicts in the country. The report says that such displaced people are more vulnerable to the risk of trafficking.

Sarkar \& Pandey (2006) draw a picture of the trafficking victims when in custody of their masters. They say that these women mostly have had an agreement to pay the traffickers 
engaging and transit expenditures from upcoming income. And when they sell them onward, this debt is passed from one to the next trafficker. These women are also charged with housing and living expenses. Their debt keep piling up, and repayment in many cases becomes impossible. As a corollary, their earnings continue to proceed to the caskets of the perpetrators, ending themselves up with no resources to break away from the captivity.

Vermeulen and van der Beken (2004) say that women trafficked for sexual exploitation purposes are usually treated far strictly than those trafficked for economic exploitation purposes. They say that the victims of former category are dealt with severely during their transportation or exploitation. Report of the commission of inquiry for women (1997) says that if they do not cooperate, their captors give them in the police custody. Once in custody, they are helpless having no access to legal assistance, and finally they again become dependent on the captors (mostly the pimps) who access them in the jail, threaten them, get them freed on bail and get the bail cancelled if they refuse to obey their orders. They cannot arrange the surety if they are freed on bail, and even have no place to go even if they manage to be out. Many of them end up with the HIV and other sexually transmitted diseases.

\section{Causes behind the Menace}

First hand impression of trafficking connotes involuntariness i.e. all being trafficked are either being done so under force contrary to their will or are being duped through false promises of job or marriage. It is very much true in case of Pakistan where large number of women are put hostage against their will for the purpose economic and sexual abuse. However, Lethi and Aromaa (2006) have found that major proportion of the victims is rather "willing to be trafficked". However, this remains a fact that though they have their volition involved; they are unaware of what actually will happen to them. They might have been dreaming of a better life but, in fact, may not be aware of their actual end-use.

They further explain that recruiting of the women is most of the time done through connections and friends who have their trust. And despite this fact that many victims seriously doubt the truth of the promises, they tend to dice their luck out of their wretched domestic situations. The authors say that in recent study in South Asia conducted over the women trafficked to neighboring countries doubted the promises being made by the traffickers but they had no other choice but to move. Hossain (1993) also agrees with this point of view and says that all victim women are not forcibly trafficked internally or externally. It is the wish of a more hopeful future that pushes them to take that risk. So much so that some women are so much disgruntled with their existing state of life that they prefer servitude and slavery and let themselves to be trafficked and sold. 
Research study conducted by Hussein, M. and Hussain, S. (2012) of the Aurat Foundation aided by USAID in 2012 on Internal Trafficking of Women and Girls in Pakistan also corroborates this view and states that poverty has often forced even parents to become accomplice in the offense of trafficking by straightaway selling their children or accepting compensation in lieu of the abducted children. The report quotes a trafficker under arrest as having said:

"If people voluntarily bring a girl and sell her to me, I show her to the buyer and tell him have a look. It is up to you. I only do what the whole world is doing. It is not just me; thousands are involved in this business... Just like people bring goats to those who are known as traders of goats, people bring women to someone who is a trader of women."

This report also highlights that most of the abducted and trafficked women and children in Pakistan finally land in forced labor in the provinces of Sindh and southern Punjab mainly for farming, brick-kiln industry, carpet-making, and the glass bangle making. Besides, young boys and girls are also traded and rented for begging, domestic servitude and prostitution.

Paul, B. K.\& Hasnath, S. A. (2000) are of the view that apart from economic ramshackle, traffickers also exploit social, and cultural vulnerabilities of the women in the South Asian countries. Women in this region are the most exposed ones to the trafficking experience that collectively emanates from the factors like indigence, gender disparity and bigotry, abysmal literacy rate, ignorance of legal right and access, enervated legislation and the poor enforcement of anti-trafficking laws. Due to accumulative effect of these factors, the victims remain diffident even to access the legal system. Shah (2004) agrees and says that these factors act in combination to bring about plight of the women in this region. While hailing from a very weak financial background, and combined with illiteracy and ignorance amidst highest level of social injustice, crime against humanity, extreme brutally of the women's rights, and lawlessness in general, these women become an easy prey of the exploiters.

\section{Connivance of Law-Enforcement Agencies}

Most of the times, traffickers come from organized crime consortia at national and international levels. They carry out this heinous crime in connivance and alliance with the corrupt police and other law-enforcement agencies in Pakistan, India, and Bangladesh. These agencies help the culprits orchestrate the facilities required for trafficking like means of transportation and stay. Momen (1993) says that certain crooked border agency officials in Bangladesh abet in haulage of the trafficked women over the national frontier for pecuniary reap and sexual favors. Reportedly, some frontier agency officials keep 
women of their choices with them till arrival of the next lot of trafficked women. Hossain (1993) says that there is sufficient evidence that several wronged families in Bangladesh inform the police with names of the women traffickers but the police has always been seen baulking at proceeding against the perpetrators. Cases instituted by the police contain weak evidence against the perpetrators and most of the times these cases are summarily rejected by the courts because of this reason.

So involvement of the law enforcement agencies in this matter is a deciding factor. This trade could not be run without active support of the police. Ironically, whenever they conduct a raid conducted, it is the victims only who are nabbed rather than the culprits. Trafficked women recovered during such raids are further victimized by the police and the legal system, which treat them as criminals. The victim women are booked, conversely, under Hudood Ordinance and the Passport Act. In any case, they have to spend long periods in prison. In most cases, raids and arrests point out a broken deal between the police and the trafficking syndicate over the graft disputes.

\section{Methods of Research}

This research work is primarily based on a review of secondary literature and interviews with the trafficking victims and the officials of the agencies engaged in prevention of human trafficking and the officials from certain NGOs working towards rehabilitation of the victims. Primary data was collected through interviews with the 65 trafficking victims, majority of them lodged in the various shelter houses in Karachi to get first hand information about their ordeals in order to gain an insight into the dynamics of menace of internal trafficking in Pakistan. Besides, this study also used periodic reports produced by various bodies like United Nations Office on Drugs and Crime report, Pan American Health Organization report, Asian Human Rights Commission report, and Trafficking in People Report (TIP) published by the United States Department of State

It is believed that the data available for this study to answer the research questions given above are less than adequate since being clandestine activity linked to organized crime, women trafficking remains under reported since most of the victims are already wretched and helpless. They do not think about reaching to the authorities out of fear of reprisal on part of the traffickers or because of lack of any hope of being heard. Parents and guardians of many victims even believe that getting the incident reported can bring them further embarrassment and humiliation. Even, securing confidence of the victim women for an interview for the purpose of this study was a daunting task. Lots of work had to be done to convince them about objective of the interviews. Interviews were structured and most of the respondents talked very briefly to the questions asked. Only a few respondents spoke little expansively. Furthermore, most of the data made available by the law enforcement agencies was a cumulative data suggesting figures about the human 
trafficking at large rather than being women trafficking specific, so less than optimum data was collected for this study.

\section{Data Integration}

\section{Reasons to Fall in the Trap of Traffickers}

In response to this question, $58 \%$ said their current life was miserable due to poverty. They were told about promising life if they moved out. Another $40 \%$ said they fled their houses after having contracted marriage with the traffickers. But later the marriage proved fake and dud. Only $2 \%$ comparatively younger women believed that moving out of their home will expose them to an opportunity of education that they could not have at their own home. Response to this question is summarized graphically in the following diagram.

\section{Chart 1}

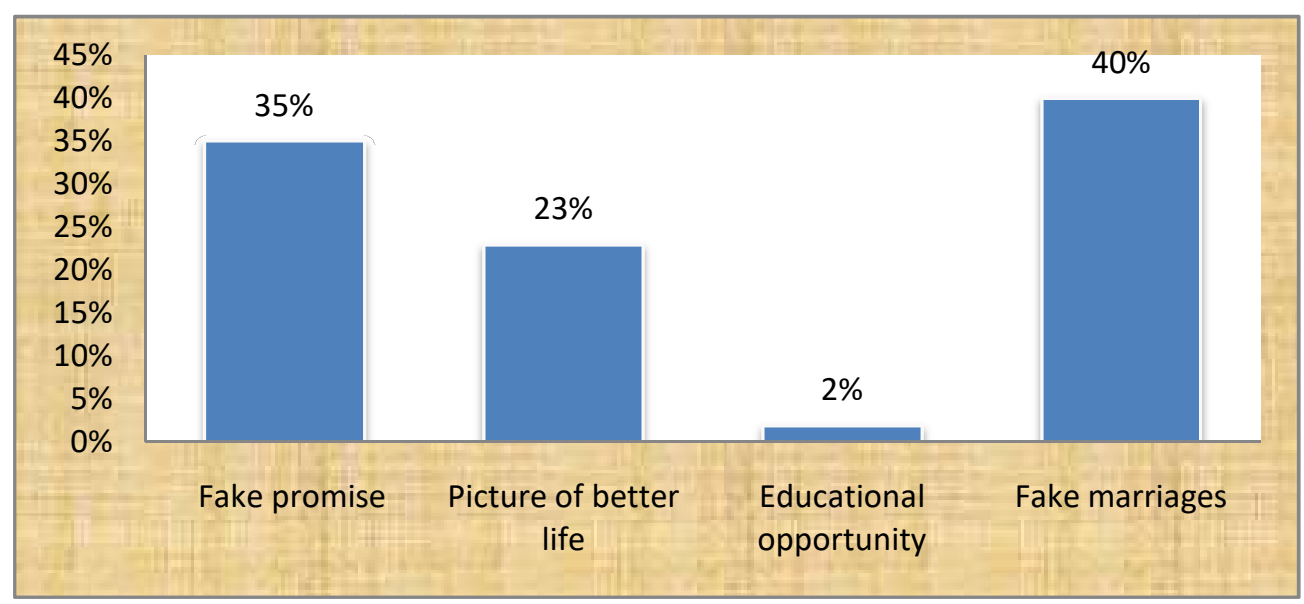

\section{First Contact with Traffickers}

In response to this question, $80 \%$ of the interviewees told that the traffickers met them either through their relatives or friends. Only $18 \%$ said that they were contacted by the traffickers. Response to this question is summarized graphically in the following diagram. 
Chart 2

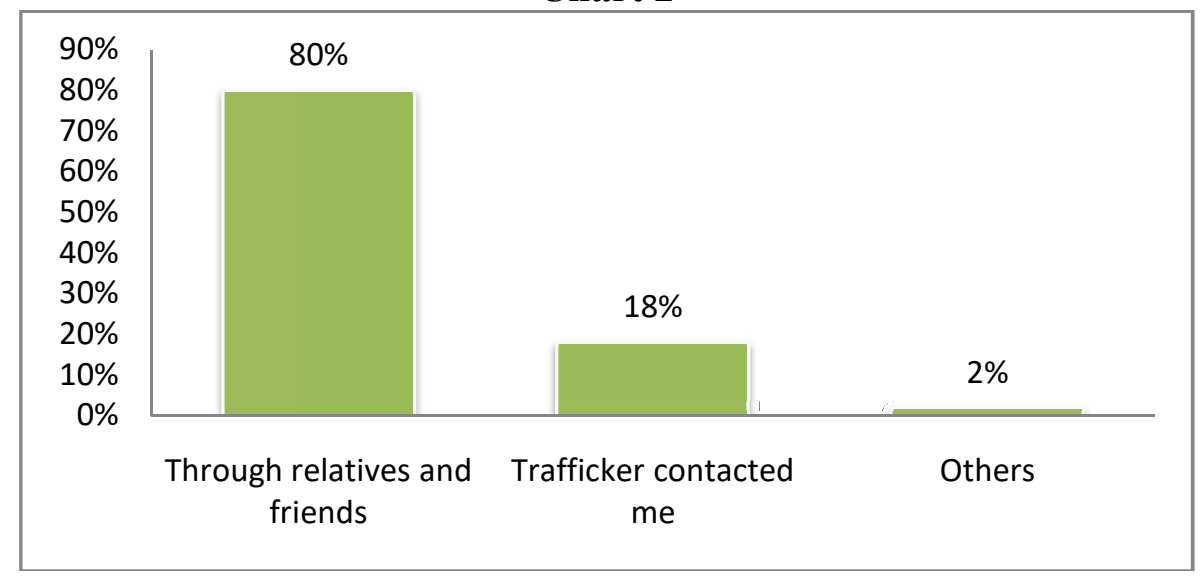

\section{Ways of Recovery/ Escape}

In response to this question, $80 \%$ said they were recovered by police, $15 \%$ told that they ran from the trap when they found opportunity. Through interviews with the NGOs, it was revealed that recoveries made through police were actually made on the behest of the NGOs, and not by the police on their own. Five comparatively older women from this category told that they had had an opportunity to escape when they were made to beg at the public places. Two women told that they shouted and called for public help when they were made to beg in public places. Agents of the traffickers who were standing guard for them fled. Subsequently, they were moved to the shelter house. $2 \%$ of the respondents who were involved in external trafficking said they were rescued when caught abroad and deported. Response to this question is graphically summarized below.

\section{Chart 3}

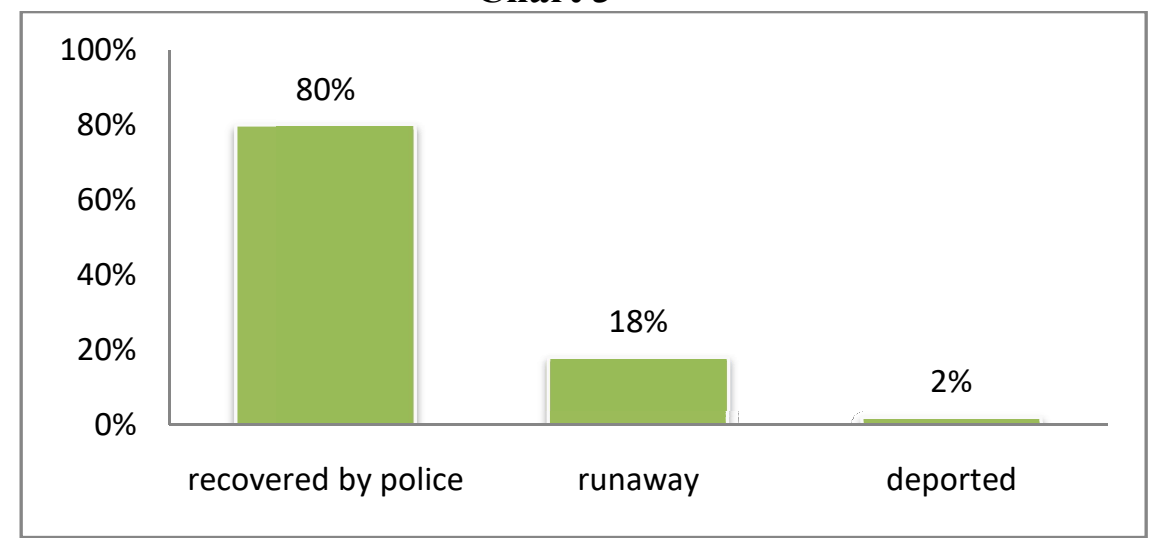




\section{Registration of Case to Police}

Answer to this question was weird. $65 \%$ of the women said the police registered the case themselves. They know this because they are taken to the court for hearing each month. $30 \%$ of them said they did not register any case with police. This category included $18 \%$ of the women who had managed to escape from the trap. While the remaining 5\% had no idea whether any case was registered with the police because they had never been taken to the court from the shelter houses. Response to this question is graphically summarized below.

\section{Chart 4}

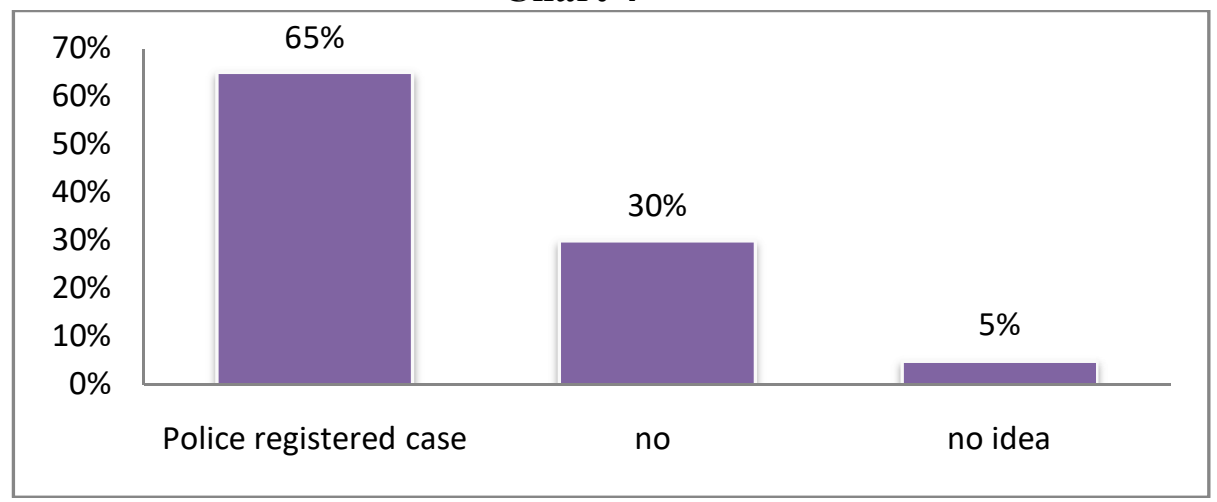

\section{Availability of Medical Help at the Time of Rescue}

$85 \%$ of the respondents believed that their regular medical check-up has been conducted since their lodging in the shelter houses. However, all 5\% respondents who had joined their families rather than being lodged in the shelter houses said that they have never been shown to the doctors since their return. However, $10 \%$ of the respondents lodged in the shelter houses believed that only occasionally they are shown to the doctors. Response to this question is graphically summarized below.

\section{Chart 5}

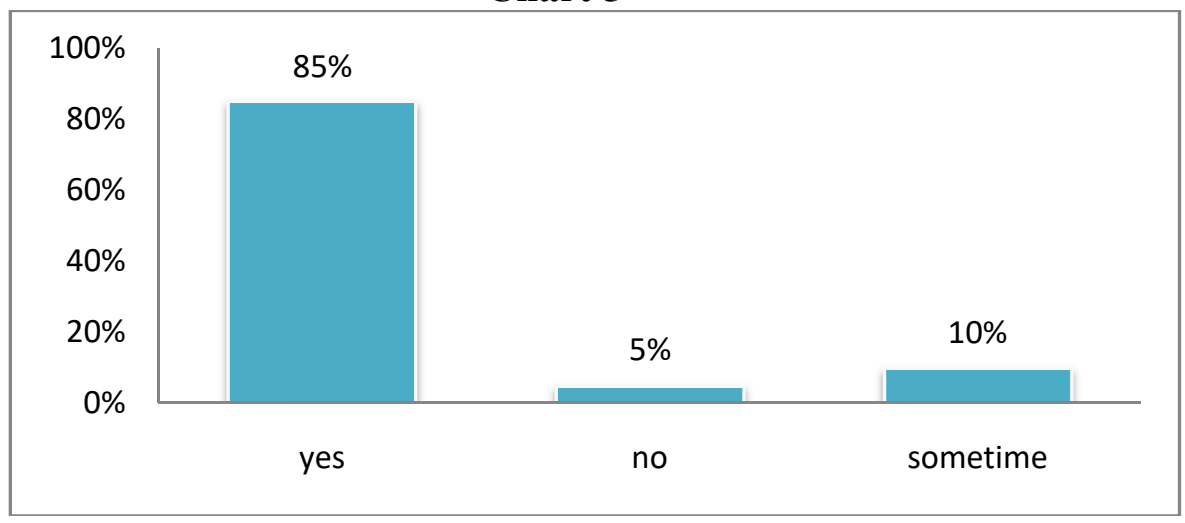




\section{Availability of Legal Health}

Response to this question was a replica of the previous questions. Those $85 \%$ of the respondents who said that regular medical help was available to them said that legal aid was also available to them. They told that when they go to the court, they are received by a lawyer. It looked the source of medical and legal aid was common. Likewise, all 5\% respondents who had joined their families rather than being lodged in the shelter houses said that they have never been taken to the court. Even they did not know whether any case had been registered with the police on their behalf. $10 \%$ of the respondents lodged in the shelter houses said they have no idea whether they have been provided a lawyer or not. Response to this question is graphically summarized below.

Chart 6

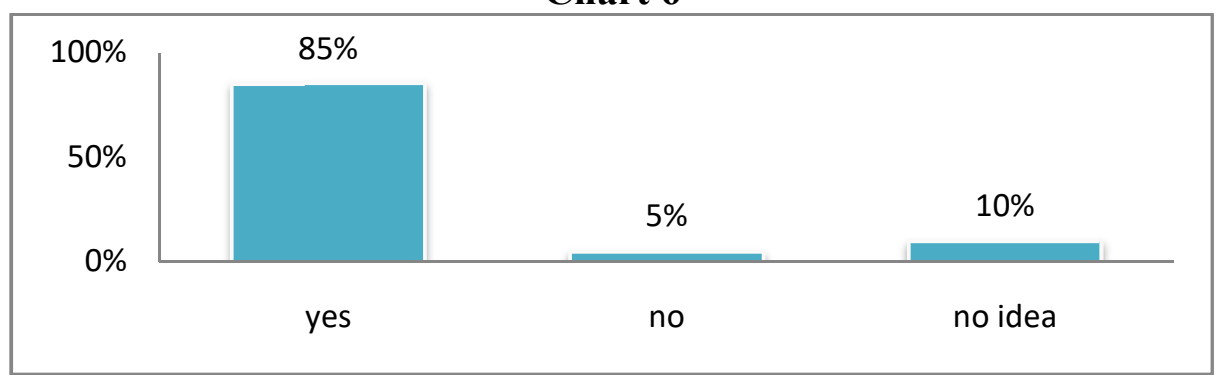

\section{Views about the Condition of Shelter Homes}

When respondents were asked how you found the place they were lodged in, a whopping majority remained silent. These women included all those who had been reunited with their families. True to the common impression, $20 \%$ of them said that it was better than their own house. This response showed an agreement with the response to question No. 1 whereby it was told that they had been undergoing miserable life at their home owing to poverty. However, 15\% respondents lodged in the shelter houses were taking it as blessing when compared to their confinement and torture at the hand of the exploiters. Response to this question is graphically summarized below. 


\section{Chart 7}

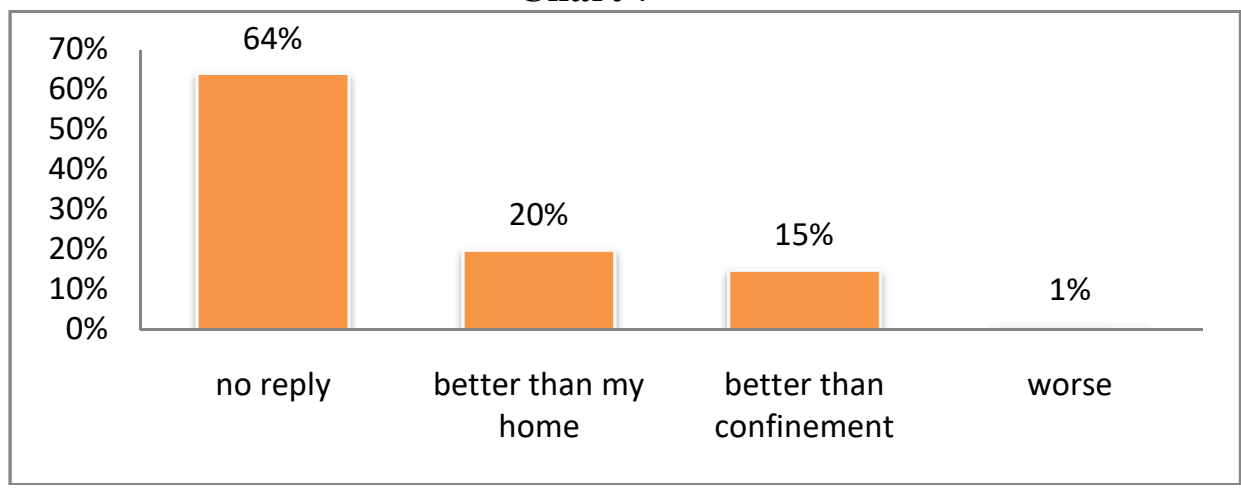

\section{Views about Returning Home}

Painfully, $30 \%$ of the respondents said no to this questions. This category included all those women who had previously said that shelter houses were better than their own home, or they had left their home out of misery inflicted to their lives. But more devastatingly, the highest number $(50 \%)$ of the respondents said that they wanted to return to their homes but they apprehended that their families will not accept them back in their fold. However, $20 \%$ of those who had been lodged in the shelter houses were willing to return to their home and hoped they will be accepted by their families. Response to this question is graphically summarized below.

\section{Chart 8}

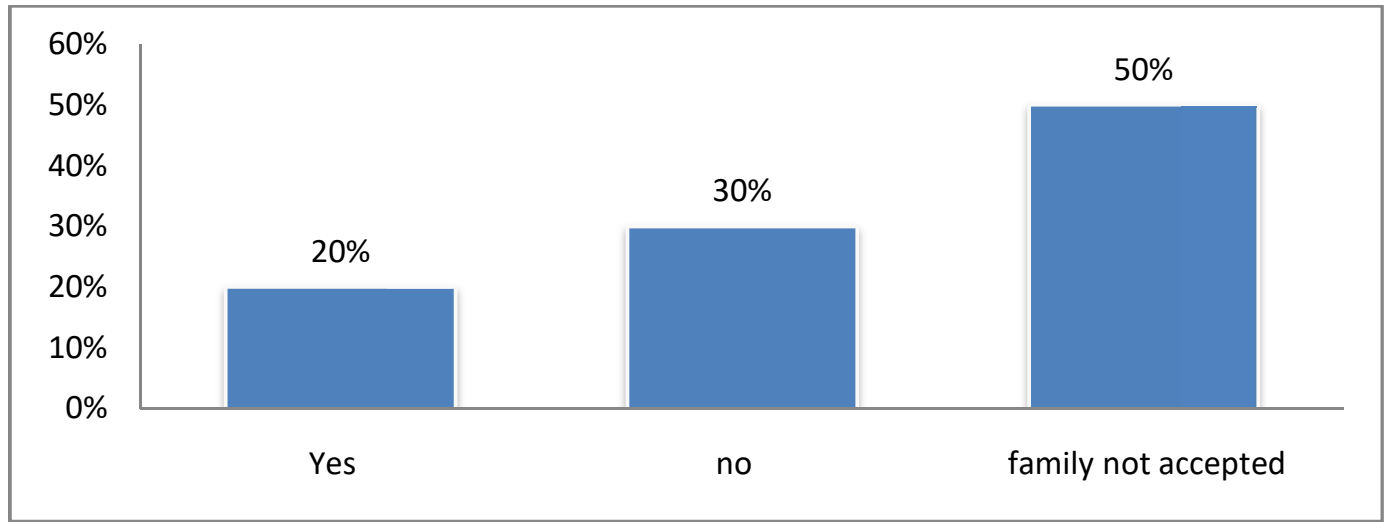

\section{Support of NGOs}

Response to this question again had lot of correspondence with the questions 4 and 5 . Whopping majority of the women (85\%) lodged in the shelter houses believed NGOs were helping them in their treatment, food, teaching technical skills and even to reunite them with their families if they wanted. Those 5\% living with their families said no NGO 
had reached them. While $10 \%$ of the women lodged in the shelter houses did not know who was defraying their expenses. Response to this question is graphically summarized below.

\section{Chart 9}



\section{Exploiters Behavior with Respondents}

When asked how the exploiters controlled you during captivity, $40 \%$ of them said they simply confined them most of the time however, they were fed sufficiently. $30 \%$ of them said they kept consoling them for meeting the promises. $20 \%$ of them said that they were tortured and sexually abused while $10 \%$ reported that they were frequently threatened to keep them calm. Response to this question is graphically summarized below.

Chart 10

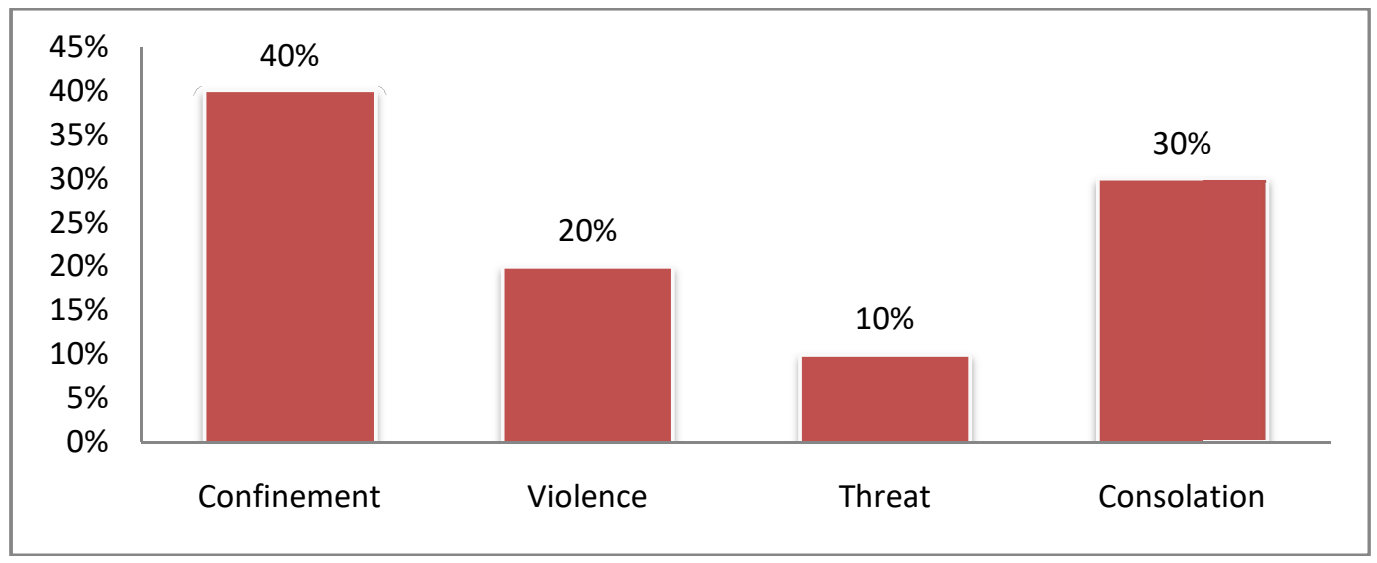




\section{Discussion \& Conclusions}

The study has shown that the factors that promote women trafficking in Pakistan include poverty, illiteracy on part of the women and lust for financial gains and criminal intent on part of the traffickers amidst social injustices, and injustices imbedded in the patriarchal dimension of the society and deeply held beliefs and customs that do not even view internal trafficking as offence to the women and society. Besides, abysmal rate of reporting the trafficking incidents and inadequate enforcement of the existing antitrafficking bolster this menace to continue unabated.

None of the interviewees in the course of study said that she was trafficked under duress. Rather all of them confessed to having moved by their own will. 58\% said their current life was miserable due to poverty. They were told about promising life if they moved out. Another $40 \%$ said they fled their houses after having contracted marriage with the traffickers. But later the marriage proved fake and dud. Only $2 \%$ comparatively younger women naively believed that moving out of their home will expose them to an opportunity of education that they could not have at their own home. These findings support the claim of Lethi and Aromaa (2006) that a good number of the victims are rather "willing to be trafficked". But the authors had contended that such naïve women venture out of their inanity and naivety for green pastures though they never knew that what they had dreamt would never be realized. Findings of this study have proved this point. All sixty interviewees who fled their house without any apparent duress ultimately ended up in a nightmare.

Furthermore, this study has also proved another point of the literature review that most of such women are recruited through connections and friends. $80 \%$ of the interviewees told that the traffickers met them either through their relatives or friends. Only 18\% said that they were contacted by the traffickers. Lethi and Aromaa (2006) had already said that recruiting of the women is most of the time done through acquaintances who have their trust. The authors further had said that in spite of this fact that many victims seriously doubt the truth of the promises, they tend to dice their luck out of their wretched domestic situations. These findings also approve the point of Hossain (2003) that some women are so much disgruntled with their existing state of life that they prefer servitude and slavery and let themselves to be trafficked and sold.

The latter point is proved in this study when $30 \%$ of the respondents said they do not want to go back to their family because of the predicament their families were already suffering from and because of which they had to flee their home. Apprehension of 50\% of the respondents that their families would not accept them back in their fold supports this point that these women moved with the traffickers by their own volition. 
Findings of this report also expose a gruesome dimension of our society - some parents even searched the traffickers for selling their daughters out of poverty. These findings support the point raised by the research study conducted by Hussein, M. and Hussain, S. (2012) of Aurat Foundation aided by USAID in 2012 on Internal Trafficking of Women and Girls in Pakistan that concludes that penury often forces even the parents to become party in the offence of trafficking either by selling their children or by accepting recompense in lieu of their abducted children.

This study also unearthed the state of the women while in confinement of the traffickers. $35 \%$ of the respondents said that they were subjected to physical torture, $15 \%$ said that they were threatened of having killed them or maimed if tried to escape or if not obeyed the orders of their owners. $40 \%$ of the respondents said that they were kept confined for most of the time and subjected to sexual exploitations though they were not subjected to physical torture because they "cooperated" with them. $25 \%$ of the interviewees, however, said that their captors kept consoling them to fulfill the promises made but they never did it till end. This point of the findings of this study support the early findings of Sarkar \& Pandey (2006) who had said that the traffickers keep the victim women dependent upon themselves by keeping them financially helpless. They charge the women with housing and living expenses also. This debt keeps piling up, and paying back becomes impossible in many cases. In the result, their earnings continue to proceed to the pockets of the perpetrators, ending themselves up with no resources to break away from the captivity.

These findings also agree with the report of the commission of inquiry for women (1997) which states that if these women do not cooperate with the exploiters, they give them in the police custody, and once in custody, they are helpless having no access to legal assistance, and finally they again become dependent on the exploiters.

Other dark side of the findings is that a large number of victims had not registered their cases with the police. $30 \%$ of them said they did not register any case with police. This category included $18 \%$ of the women who had managed to escape from the trap. However, $65 \%$ of the women said the police registered the case themselves. They know this because they are taken to the court for hearing each month. While the remaining 5\% had no idea whether any case was registered with the police because they had never been taken to the court from the shelter houses. Response to this question is graphically summarized below.

It concludes that there are multiple factors that underpin this gruesome business in Pakistan. These are poverty, illiteracy, helplessness of the women in this patriarchal society, and the unscrupulous customs that do not recon women trafficking as an offence to the mankind and the society. The women hailing from a very weak financial background, and combined with illiteracy and ignorance amidst highest level of social 
injustice, crime against humanity, extreme brutally of the women's rights, and lawlessness in general, these women become an easy prey of the exploiters.

\section{Recommendations}

Based on the research work conducted, following are some recommendations that may prove beneficial in curbing the menace of women trafficking:

a) Enhancing awareness of the general public. Print and electronic media can play crucial role in this regard through running a continuous campaign especially in the local languages.

b) Enforcement of the existing law relating to trafficking should be strictly enforced. In this connection, elected governments have to exercise their political and administrative will. For that purpose, the government can make more potent use of Prevention and Control of Human Trafficking Ordinance, 2002 that provides from 7 to 14 years' imprisonment to those who purchase, sell, harbor, transport, provide, detain, or obtain a child or a woman through coercion, kidnapping or abduction, or by giving or receiving any benefit for trafficking the child or woman into or out of Pakistan for the purpose of exploitative entertainment. Besides, the Bonded Labor System Abolition Act, 1992 should be used effectively that prescribes two to five years' imprisonment or a fine, or both.

c) There is needed a radical change in the mindsets of the police and other agencies dealing with the cases of women trafficking so that the perpetrators are dealt with in a befitting manner. A dedicated force on the pattern of CPLC should be established that deals exclusively with the matters of women trafficking and the consequent situations like bonded labor and prostitution. Required amendment in the law should be made forthwith.

d) Police personnel and officials from other agencies dealing with the women trafficking who are found complicit in the crime of women trafficking should be punished severely and made exemplar so that it leaves a therapeutic effect over the others. It will also restore confidence of the public in general in the police and crime reporting rate shall be enhanced.

e) The women involved in trafficking and recovered should be provided with free medical and legal aid. This can again be made possible through effective use of the Prevention and Control of Human Trafficking Ordinance, 2002 that provides for certain benefits to the victims, like paying compensation and expenses to the abused women; providing them shelter, food, and medical care.

f) There should be established more organized facilities for rehabilitation of the abused women involving equipping them with vocational skills. For that purpose public-private relationship should be intensified, and the hands of the reliable 
NGOs with sound track record should be strengthened providing them with funds to erect such facilities.

g) Counter-trafficking legislation should be strengthened and all recommendations suggested above should be made part of the law.

\section{References}

Ahmed, L.A., \& A. Sarkar (1997). For a Handful of Dreams In Star Weekend Magazine, Dhaka, 20-26 June, pp, 4-9.

AHRC (2011). Women Trafficking Across Pakistan, http://www.humanrights.asia/news/ forwarded-news/AHRC-FAT-011-2011

Ali, S.M. (2009). Development: The human trafficking problem. http://www.dailytimes. com.pk/default.asp?page $=2009 \% 5$ C04\%5C07\%5Cstory 7-4-009 pg3 3 . (accessed on June 22, 2013)

Asmita (1998). Efforts To Prevent Trafficking In Women And Girls: A Pre Study Of Media Activism, Kathmandu, pp, 7-11.

Gazi, R, Chowdhury ZH, Alam SMN, Chowdhury E, Ahmed F, Begum S. (2001). Trafficking of Women and Children in Bangladesh Centre for Health and Population Research. http://www.usaid.gov/bd/files/ trafficking_overview.pdf (accessed on July, 14, 2013)

Hajdinjak, M. (2002). Smuggling in Southeast Europe. CSD (Center for the Study of Democracy) Reports no. 10. Center for the Study of Democracy.

Hossain, H. (1993). Foreign Domestic Workers: NGO Perspectives. Development 1: pp, 41-45.

Hussein, M. \& Hussain, S. (2012). Internal Trafficking of Women and Girls in Pakistan, A Research Study, Aurat Publication and Information Services Foundation.

Javed, A. (2011). Women Trafficking. Available at http://www.ideasevolved.com/women -trafficking December (accessed on June 26, 2013.

Khowaja, S., Jawed, A., Agha, T.\& Karamaliani, R. (2012). Women Trafficking: Causes, Concerns, Care!, Journal of Pakistan Medical Association, Vol. 62(8), pp, 835-38

Lehti, M. \& Aromaa, K. (2006). Crime and Justice, Vol. 34, No. 1, pp. 133-227 
Lin, S. G., and M. C. Paul. (1995). Bangladeshi Migrants in Delhi: Social Insecurity, State Power, and Captive Vote Banks. Bulletin of Concerned Asian Scholars 27 (1): pp, 3-20.

Momen, A. (1993). Congressional Hearing on Asian Slave Trade. Human Rights Caucus, United States House Representatives. Washington, D.C., 15 July. Unpublished Text of a Presentation.

Niemi-Kiesilainen, J. (2004). Naiskauppa, Paritus Ja Seksin Osto. Lakimies 3: pp, 451-65.

Pan American Health Organization (2001). Trafficking For Sexual Exploitation. Fact Sheet Women, Health \& Development Program, http://www.paho.org/English/ ad/ge/trafficking.pdf. (accessed on July 30, 2013)

Paul, B. K. \& Hasnath, S. A. (2000). Trafficking In Bangladeshi Women and Girl, Geographical Review, Vol. 90 (2) pp, 268-276

NCSW (1997). Report of the Commission of Inquiry For Women. Pakistan.

Shah, S. (2004). Women Trafficking - The Hidden Truth, Pakistan Press Foundation. http://www.pakistanpressfoundation.org/views-and-opinions/25887/womentrafficking-the-hidden-truth/ (Accessed on July 30, 2013)

Sarker, P.C. \& Panday, P.K. (2006). Trafficking In Women And Children In Bangladesh: A National Issue In Global Perspective In Asian Journal of Social Policy. 14(2)

Shahinian, G. (2002). Trafficking In Women \& Girls. http://www.un.org/womenwatch/ daw/egm/trafficking2002/reports/EP-Shahinian.PDF. (accessed on July 30, 2013)

Truong, T. D. (2006). Poverty, Gender And Human Trafficking In Sub-Saharan Africa: Rethinking Best Practices In Migration Management. http://unesdoc.unesco. org/images/0014/001432/143227e.pdf. (accessed on May 30, 2013)

UNICEF (2002). Welcomes Signing of Two Conventions on Children by South Asian leaders. http://www.unicef.org/newsline/02pr01.htm.

UNODC (2008). Human Trafficking: An Overview, http://www.ungift. org/docs/ungift/pdf/ knowledge/ebook.pdf. (accessed on July 14, 2013) 
United Nations Office on Drugs and Crime (2004). UN United Nations Convention Against Transnational Organized Crime And The Protocols There to. http://www.unodc.org/documents/treaties/UNTOC/Publications/TOC\% 20Convention/TOCebook-e.pdf. (accessed on July 17, 2013)

US States Department (2011). Trafficking In Persons Report 2011. http://www.state.gov/ $\mathrm{j} /$ tip/rls/tiprpt/2011/index.htm (accessed on July 20, 2013)

US States Department (2013). Trafficking In Persons Report 2013. http://www.state.gov/ $\mathrm{j} /$ tip/rls/tiprpt/2013/index.htm (accessed on July 20, 2013)

Vermeulen, G. \& Tom, van der Beken (2004). Belgium In A Study for Monitoring The Trafficking of Human Beings For The Purpose Of Sexual Exploitation In The EU Member States, Unpublished final draft. Helsinki: HEUNI.

Zimmerman, C., Kiss, L., Hossain, M. \& Watts, C. (2009). Trafficking In Persons: A Health Concern? Ciência \& Saúde Coletiva 1029-1035. Available from URL: http://www.scielosp.org/ scielo.php?script=sci arttext\&pid=S1413-81232009000400010 (accessed on July 10, 2013)

Dr. Farooq-e-Azam Cheema is Head of Management Sciences Department, Bahria University Karachi Campus, Karachi.

Prof. Dr. Tayyaba Zarif is Chairperson in the Department of Education, Shaheed Benazir Bhutto University - Shaheed Benazirabad.

Aziz - un- Nisa is Assistant Professor in Department of Education, University of Karachi. 